\title{
Correction to: A randomised controlled feasibility study of interpersonal art psychotherapy for the treatment of aggression in people with intellectual disabilities in secure care
}

Simon S. Hackett ${ }^{1,2^{*}}$, Ania Zubala ${ }^{3}$, Katie Aafjes-van Doorn ${ }^{4}$, Thomas Chadwick', Toni Leigh Harrison², Jane Bourne ${ }^{2}$, Mark Freeston ${ }^{1}$, Andrew Jahoda ${ }^{5}$, John L. Taylor ${ }^{2,6}$, Cono Ariti ${ }^{7}$, Rachel McNamara ${ }^{7}$, Lindsay Pennington ${ }^{1}$, Elaine McColl ${ }^{1}$ and Eileen Kaner ${ }^{1}$

Correction to: Pilot Feasibility Stud 6, 180 (2020)

https://doi.org/10.1186/s40814-020-00703-0

Following publication of the original article [1], the authors reported an error in author 3's last name. The correct last name should be "Aafjes-van Doorn" instead of Aafjes-van Doorm.

The original article has been corrected.

\section{Author details}

${ }^{1}$ Faculty of Medical Sciences, Newcastle University, Newcastle upon Tyne, UK.

${ }^{2}$ Cumbria, Northumberland, Tyne \& Wear NHS Foundation Trust, Newcastle upon Tyne, UK. ${ }^{3}$ University of the Highlands and Islands, Inverness, UK.

${ }^{4}$ Yeshiva University, New York, USA. ${ }^{5}$ Glasgow University, Glasgow, UK. ${ }^{6}$ Northumbria University, Newcastle upon Tyne, UK. ${ }^{7}$ Centre for Trials

Research, Cardiff University, Cardiff, UK.

Published online: 18 December 2020

\section{Reference}

1. Hackett SS, Zubala A, Aafjes-van Doorn K, et al. A randomised controlled feasibility study of interpersonal art psychotherapy for the treatment of aggression in people with intellectual disabilities in secure care. Pilot Feasibility Stud. 2020;6:180 https:/doi.org/10.1186/s40814-020-00703-0.

The original article can be found online at https://doi.org/10.1186/s40814020-00703-0.

*Correspondence: simon.hackett@newcastle.ac.uk

${ }^{1}$ Faculty of Medical Sciences, Newcastle University, Newcastle upon Tyne, UK

${ }^{2}$ Cumbria, Northumberland, Tyne \& Wear NHS Foundation Trust, Newcastle upon Tyne, UK

Full list of author information is available at the end of the article

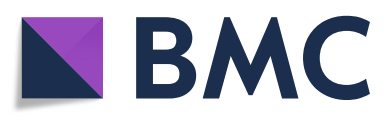

(c) The Author(s). 2020 Open Access This article is licensed under a Creative Commons Attribution 4.0 International License, which permits use, sharing, adaptation, distribution and reproduction in any medium or format, as long as you give appropriate credit to the original author(s) and the source, provide a link to the Creative Commons licence, and indicate if changes were made. The images or other third party material in this article are included in the article's Creative Commons licence, unless indicated otherwise in a credit line to the material. If material is not included in the article's Creative Commons licence and your intended use is not permitted by statutory regulation or exceeds the permitted use, you will need to obtain permission directly from the copyright holder. To view a copy of this licence, visit http://creativecommons.org/licenses/by/4.0/ The Creative Commons Public Domain Dedication waiver (http://creativecommons.org/publicdomain/zero/1.0/) applies to the data made available in this article, unless otherwise stated in a credit line to the data. 